\title{
Библиотеке и библиотекари у уметничкој књижевности и популарној литератури
}

\author{
Милица Матијевић \\ Библиотека „Димитрије Туцовић”, Лазаревац \\ milica.biblioteka@gmail.com \\ Виолета Ђорђевић \\ Библиотека града Београда \\ violeta_djordjevic@yahoo.com
}

\begin{abstract}
Сажетак
У раду се анализира начин представљања библиотека и библиотекара у савременој српској књижевности. Мада се ретко појављују као мотив у делима домаћих аутора, они су ипак присутни, како у у књижевности за децу, тако и у свим родовима књижевности за одрасле. Разматрају се уобичајени стереотипи на којима се заснива слика библиотека и библиотекара. Такође, откривају се нови, савремени стереотипи који постепено замењују оне из ранијих периода. Приказом одређених књижевних дела истражује се улога књижевног стваралаштва на креирање слике о библиотекама и библиотекарима у јавности, као и у којој мери савремена српска књижевност доприноси или се супротставља постојећим стереотипима. Рад преиспитује у којој мери су сами библиотекари свесни уврежених представа о себи и својој професији у савременој домаћој уметничкој књижевности и популарној литератури.
\end{abstract}

Кључне речи: библиотеке, библиотекари, стереотипи, књижевност, јунаци, књига

\section{Увод}

У делима савремених српских писаца библиотеке и библиотекари не појављују се често. У савременој домаћој књижевности припадници библиотекарске професије ретко су јунаци и као споредни, а поготово као главни ликови. Када су заступљени у уметничкој књижевности и популарној литератури, библиотеке и библиотекари су представљени кроз уобичајене стереотипе. Интересантно је да стереотипне карактеристике постоје и у делима писаца који ову професију сагледавају озбиљније и схватају шире. Избором управо тих дела у раду ће бити размотрена могућа улога књижевног стваралаштва на креирање слике о библиотекама и библиотекарима у јавности, као и у којој мери савремена српска књижевност доприноси или се супротставља постојећим стереотипима. Стога је предмет овог рада приказ представа библиотека и библиотекара у домаћој књижевности, са свим својим специфичностима.

\section{Стереотипи о библиотекарима}

Многи научници и истраживачи на јединствен начин сагледавају стереотипе као карактеристике које описују припаднике одређене групе. Стереотипи су најчешће засновани на уопштеним уверењима и претпоставкама. Представљају искривљене или поједностављене идеје или слике о одређеној групи. Били позитивни или негативни, стереотипи се примењују неселективно на све чланове групе.

Ајлин Р. Атербури указује да је традицонални стереотип о професији библиотекара по којем је она слабо плаћен женски посао који обављају неудате старије жене са пунђом, 
наочарима и у сукњи од твида, повучене и недружељубиве, једнако неприхватљив као и стереотип новог доба по коме је библиотекарка секси уседелица, тетовирана, са косом у свим бојама дуге. ${ }^{1}$

Традиционални стереотипи пре свега су усмерени на жене, али и мушкарци у нашој професији имају своје стереотипне карактеристике. Они су недруштвени, претерано стреме реду, строго воде рачуна о правилима. Овакве особине доводе до једног од уобичајених стереотипа - библиотекара-полицајца који више брине о заштити колекција него о могућностима њиховог коришћења. Екстремни облик овог стереотипа је психобиблиотекар, који се јавља и у домаћој научној фантастици. ${ }^{2}$ Особине које се често везују за библиотекаре су интелигенција и стидљивост, тако да се као један од стереотипа јавља и библиотекар-штребер који је са својим тајним животом нека врста новог јунака. ${ }^{3}$

Најприсутнија стереотипна слика у јавности је библиотекар-књишки мољац. Стереотипи на неки начин показују шта јавност очекује од ове професије, па се тако јавља и слика идеалног библиотекара који је образован, љубазан, ентузијаста који живи за библиотеку.

Постојање одређеног стереотипа, позитивног или негативног, има утицаја и на саму професију и на сваког њеног припадника. Стога не чуди што су библиотекари забринути за своју професионалну слику у јавности. Још је Мелвил Дјуи изражавао наду да ће библиотекари постати поносни на своју професију и да ће до почетка 20. века негативни стереотипи нестати. ${ }^{4}$

Стереотипи и перцепција библиотекара у књижевности утичу на слику коју о себи имају припадници наше професије, али и јавност. Не постоји много радова нити истраживања на тему заступљености библиотека и библиотекара у уметничкој књижевности и популарној литератури. Ова врста истраживања за библиотекарство као професију од изузетног је значаја јер када трагамо за одговором како нас јавносй виgи, од посебног значаја су одређене врсте јавности, у овом случају књижевни сшивараоци. За улогу и статус библиотека и библиотекара у друштву изузетно је важно да јавност схвати каква је природа посла коју информациони стручњаци обављају. У супротном, стереотипи о библиотекарима који стишавају гласне кориснике и само задужују и раздужују књиге наставиће да постоје.

\section{О стереотипима и перцепцији библиотекара у књижевности}

У светској књижевности обраде мотива библиотеке и библиотекара имају дугу историју и широк распон. Немогуће је обухватити све објављене књиге у којима се помињу библиотеке и библиотекари. За причу о стереотипима о библиотекарима у књижевности једно од најзна-

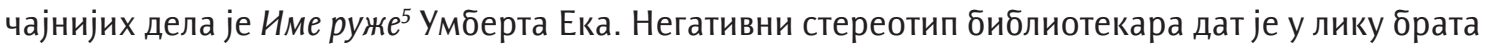
Малачија, који претерано штити своје збирке и осећа потребу да људе заштити од знања. Ништа мање стереотипан је и Кюижнички йолицајаи, ${ }^{6}$ роман Стивена Кинга у коме главни јунак ноћу посећује и кажњава људе који касне са враћањем књига. Још од средине 20. века и појаве детективског романа Леш у библиошещиㄱ Агате Кристи писци воле да радњу својих романа сместе у амбијент библиотеке. Библиотека као место непредвидивих дешавања и потенцијалне опасности може се наћи у савременом трилеру, веома популарном међу тинејџерском

\footnotetext{
1 Ilene Ramirose Atterbury, "Perceptions of a profession: Librarians and stereotypes in online videos", Library Philosophy and Practice (e-journal) (2010): 433, http://digitalcommons.unl.edu/libphilprac/433 (preuzeto 20. 6. 2017).

2 Пример за овај стереотип може се пронаћи у роману Библиошека Зорана Живковића, у поглављу „Ноћна библиотека”.

${ }^{3}$ Shaheen Majid and Azim Haider, "Image problem even haunts hi-tech libraries: Stereotypes associated with library and information professional in Singapore", Aslib Proceedings 60, 3 (2008): 229-241.

${ }^{4}$ Јелена Јаћимовић и Ружица Петровић, „Стереотипи библиотекара у јавности, популарној култури и стручној литератури”, Инфошека год.15, 1 (2014): 57.

${ }^{5}$ Umberto Eko, Ime ruže (Beograd: Novosti, 2004).

${ }^{6}$ Stephen King, Knjižnički policajac (Virovitica: TWIN PRES, 2012).

${ }^{7}$ Agata Kristi, Leš u bnog grobiblioteci (Beograd: BIGZ, 1991).
} 
популацијом, Никаg не рещи никаg, ${ }^{8}$ америчке ауторке Кети Зан. Још један савремени уврежени поглед на библиотекарску професију затиче се у роману Фрајер са сусеgної іроба, ${ }^{9}$ шведске ауторке Катарине Мазети, у коме је главна јунакиња млада, образована и савршено организована библиотекарка Дезире. Она живи у белом и минималистички уређеном стану, чита пробране књиге, носи органски памук, храни се вегетаријански, дружи се са отменим људима и удала се за човека сличног себи. Заплет настаје када после преране смрти мужа упознаје човека који је потпуно супротан њој. Управо кроз призму тих супротности на површину израњају снобовске особине ове јунакиње. Добар пример романа који велича улогу библиотека у стварању пасионираног читатеља је Гробље заборављених књиіа, ${ }^{10}$ први део трилогије Сенка вешра. То је прича о дечаку који трага за непознатим писцем и слави књиге и љубав према читању. Сафон библиотеку представља као мистичну, другачију, место велике важности за духовни развој човека.

Многи библиотекари који раде са децом волели би да су у књижевним делима представљени као љубазне, срдачне, предусретљиве, креативне особе. Ипак, не треба се много изненадити ако се у литератури за децу „баба-рога" какву срећемо у авантуристичком роману Демон школске библиошеке 11 ауторке Морее Банићевић појави баш у лику библиотекара. Библиотекарка Совић има тако незгодну нарав да је се и осмаци плаше и клоне, а била је страх и трепет генерацијама ученика, па и самом професору језика и књижевности. Јунаци овог романа су дванаестогодишњаци, за које је улазак у библиотеку у којој их чека овакав библиотекар казнени задатак и права авантура.

\section{Прикази библиотекара у савременој српској књижевности}

Као што је раније поменуто, обрада мотива библиотека и библиотекара у домаћој савременој књижевности веома је штура, али се они ипак јављају као јунаци. Како би се открили постојећи ставови и истражила евентуална промена стереотипа у савременој домаћој књижевности, важно је кренути од најмлађе популације и литературе намењене њој.

Мада се ликови библиотекара у књижевности за децу јављају изузетно ретко, могу се наћи у домаћој литератури и обрађени су са позитивним конотацијама. Лик посвећеног библиотекара, који је прави мисионар знања, беочуг између књига и читалаца, увек спреман да децу подстиче на читање, налазимо у песми Драгомира Ћулафића "Мој тата личи на библиотеку". ${ }^{12}$ Ова песма читаоцима нуди слику о библиотекару-хероју који „на књиге сасвим личи, на сликовнице, лектире, песму меку, кад јутром рано са једанаестог спрата крене са њима у библиотеку". Осим што руши уврежену представу о намрштеном библиотекару, песма у којој, између осталих, налазимо и стихове „јер књиге су вредније од злата. Ко чита књиге, тај уме да лети, оне му отварају врата" представља пример да афирмативан став о библиотекарима неретко повлачи за собом исти однос према књизи и читању.

Причу о библиотеци која обогаћује животе деце и библиотекарки-доброј вили, али и о књигама и књишким јунацима налазимо у приповетки Оливере Недељковић „Кад се тама спусти на главни градски трг". ${ }^{13}$ У овој причи библиотека је испуњена смехом, жагором и светлошћу у којој вас очекује насмејана, млада и лепа библиотекарка, али и библиотекар са брковима и

\footnotetext{
${ }^{8}$ Keti Zan, Nikad ne reci nikad (Beograd: Vulkan, 2015).

${ }^{9}$ Katarina Mazeti, Frajer sa susednog groba (Beograd: Odiseja, 2012).

${ }^{10}$ Karl Luis Safon, Groblje zaboravljenih knjiga (Beograd: Čarobna knjiga, 2017).

11 Morea Banićević, Demon školske biblioteke (Beograd: Laguna, 2016).

12 Драгомир Ћулафић, „Мој тата личи на библиотеку”, у Да ши шайнем (Зрењанин: Градска народна библиотека „Жарко Зрењанин”, 2010), 83.

${ }^{13}$ Оливера Недељковић, „Кад се тама спусти на главни градски трг”, Слова на сшируjy 20 (2016), http://www.jabooka.org.rs/product/ casopis-br-20/ (преузето 10. 7. 2017).
} 
широким осмехом испод њих. Овакве приче побијају слику библиотекарки као намрштених уседелица које ућуткују своје кориснике, а поправљају имиџ библиотекарства као пожељне и узбудљиве професије.

Почетком 20. века библиотекарство, којим су се претежно бавили мушкарци, прераста у професију у којој се у највећој мери запошљавају жене. Свет реда, каталога и правила као да је резервисан за строге и суздржане библиотекарке. Родни стереотипи присутни су и у уметничкој литератури за децу. Тако, писац Бранко Стевановић причу „Дечаци из библиотеке” духовито започиње питањем „Каква је ово глупост од наслова? Шта ће дечаци у библиотеци? Добро, може и то, али само ако су уштогљени или њањави. Библиотеке су за девојчице, за размажене принцезе, за стидљиве свезналице..." Писац у наставку објашњава да се „само шалио, да су библиотеке права места за све, па тако и за дечаке, да је у библиотекама гомила књига пуних пустоловина, несташлука и да зна за неке дечаке који готово никада не излазе из библиотеке". ${ }^{14}$

У песми Оливере Недељковић „Библиотекарке” ${ }^{\prime 15}$ видљив је стереотип по коме је то професија која стреми мери и реду. Једноличан ритам, обичан изглед, пасивно живљење, само су маска. Иза озбиљне, круте, строге „књижничарке тишине” са „књишком прашином” крије се жена свесна да

„... о књигама шапућемо и кад не говоримо

о нељубави...

ништа не пропустивши, осим живота".

Нови лик библиотекарке, који нуди ова песма, је страсна жена која се нада занимљивом заплету. Са становишта утицаја на јавно мњење, за библиотекаре је значајно да их корисници и средина доживљавају као поуздане и озбиљне, али је од изузетне важности да их виде као креативне ентузијасте који се, осим организације, баве помагањем људима и да пронађу праве информације. А за то је потребно и мало емпатије и страсти.

Интересантно је да се у страној литератури библиотекари мушког пола чешће јављају као главни јунаци, док су у домаћој литератури главни протагонисти најчешће жене.

У песми Мирослава Максимовића „Осмех из библиотеке”, ${ }^{16}$ која се налази у антологији Песме о библиошеци, ${ }^{17}$ главна јунакиња је

„...у библиотеци плавојка

у старој рушевној згради...

...са полуосмехом што мирише на

прашину".

Савршено се уклапа у стереотип библиотекарке (даме) у невољи која читав живот чека да је неко ослободи њене крутости и суздржаности и

„истом пажњом

ослушкивала корак писца у сали

И варљиви корак у вечној реченици".

Овакав женски лик убедљиво је најчешћи стереотип о повученој, скромној, сексуално фрустрираној уседелици. Тај архетип присутан је и у песми Раше Ливаде „Библиотекарка". 18

\footnotetext{
${ }^{14}$ Бранко Стевановић, „Дечаци из библиотеке”, у Овако је шео било (Нови Сад: Дневник, 2010), 7-8.

${ }^{15}$ Из необјављеног рукописа

${ }^{16}$ Мирослав Максимовић, „Осмех из библиотеке”, у Песме о библиошеии (Београд: НБС, 2003), 57-58.

17 Љиљана Ђурђић, прир., Песме о библиошеии (Београд: НБС, 2003).

18 Раша Ливада, „Библиотекарка”, у Песме о библиошеци (Београд: НБС, 2003), 59-60.
} 
„Џеџи у мемли...

А дух јој тајанствен Ограничен

Куља у ноћ Уредно сврстану

На полицама...".

Примећује се како се њен свет реда окренуо против ње и контрола коју она успоставља над библиотеком контролише и њу саму. Писац јој, са подсмехом и сажаљењем, одузима суштинске атрибуте женствености, али и људскости, стиховима

„Преживеће једино она у

Своме рају Међу жохарима

И скамењеним маљама..."

Не срећу се често овако негативни стереотипи о библиотекарима. Са јачањем делатности односа са јавношћу у библиотекама они постепено ишчезавају.

У савременој домаћој уметничкој књижевности постоје и дела у којима су припадници наше професије представљени изузетно позитивним атрибутима, што пружа добру основу и олакшава промоцију струке. Приповетка „Шта ли сада ради Оливера Јеремић”, 19 аутора Владана Матијевића, духовита је слика у којој се види библиотекарка као повучена, недруштвена, слабо плаћена (шверцерка кроз чију причу се упознаје лик библиотекарке заради за једну туру више него она за месец дана), друштвено деградирана особа, али интелигентна, духовита, задовољна својим животом. Она је неко ко се залаже за своју професију, стоји чврсто иза свог система вредности и уме да га одбрани са осмехом.

Тешко је пронаћи лик из савремене српске поп културе који је оставио јачу слику о припадницама библиотекарске професије од лика Оље Мирановске из филма Варљиво леш̄о 1968, рађеног по истоименом сценарију Гордана Михића. Појава овакве јунакиње уклапа се у стереотип новог доба о секси библиотекарки, а који је настао као последица „слављења женске сексуалности у популарној култури". ${ }^{20}$

И у роману Триезарија Виолете Ивковић разоткрива се још један традиционални стереотип да библиотекари већи део радног времена проводе удобно смештени у фотељама, читајући занимљива штива. Послови информационих стручњака, сложени системи складиштења и чувања информација, који често не подразумевају непосредан додир с књигама, широкој јавности остају недокучиви. Ову појаву најбоље је описао Иво Андрић, рекавши да је библиотекар веома сличан неком вредном сељаку, који од бројних послова на њиви не стиже да ужива у лепоти природе, а да многи библиотекари од других обавеза често не стигну на послу да уживају у лепоти писане речи. Ова чињеница неретко постаје узрок разочарања и самих библиотекара. То, у појединим деловима, предочава управо поменути роман. „Није овако замишљала посао библиотекарке. Надала се непосредном додиру с књигама, блискости која би могла да изнедри више од бескрајних низова скраћеница и бројки. Скупине немуштих таблица подсетиле су је на опсену куће књига, преобличену у бројчане записе за збрајање шифрованих наслова. Стварне су биле једино књиге, и приче у њима. Али, ни њих више нема. Виртуелне библиотеке на циркуској вртешци са убројањеним писцима у главним тачкама". ${ }^{21}$

У потрази за књижевним делима у којима су библиотекари и библиотеке књижевни јунаци, уочава се да се они најчешће јављају код писаца који су и сами били или су још увек

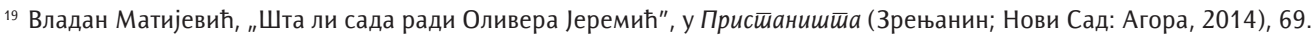

${ }^{20}$ Ilene Ramiros Atterbury, "Perceptions of a profession: Librarians and stereotypes in online videos", 433.

21 Виолета Ивковић, Трйезарија (Панчево: Мали Немо, 2009), 7-8.
} 
библиотекари. ${ }^{22}$ Овај феномен могао би се протумачити настојањем библиотекара да и овим путем покушају да приближе јавности библиотекарство као професију. У јавним библиотекама, барем на нашим просторима, није реткост да се међу запосленима нађу писци. Одговор на питање да ли је реч, пре свега, о писцима који раде као библиотекари или библиотекарима који се баве и писањем, препустићемо њима самима. Овде је много важнији моменат, који је потребно још једном истаћи, да су управо библиотекари-писци особе које своју професију најчешће уносе у књижевна дела, вајају библиотекаре као књижевне ликове и утичу на креирање и рушење и позитивних и негативних стереотипа.

У трагању за делом у коме се библиотека, књига и читање појављују као централне теме, коначно, наилазимо на дело овенчано светском наградом за фантастику 2004. године, роман Библиошека Зорана Живковића, професора, књижевног теоретичара, преводиоца и светски признатог аутора фантастике. ${ }^{23}$ Она спада у једно од најпревођенијих дела новије српске прозе. ${ }^{24}$ Књига обједињава шест прича: „Виртуелна библиотека”, „Кућна библиотека”, „Ноћна библиотека", „Паклена библиотека”, „Најмања библиотека” и „Отмена библиотека”. Кроз ових шест временски и просторно измештених прича, које нису строго повезане, али чине компактну целину, слика библиотеке се често налази на граници између реалног и фантастичног. Можда најкарактеристичнија прича је „Ноћна библиотека”, где је библиотека представљена као место где је нужно доћи тачно у оквирима радног времена, где минут кашњења посетиоца осуђује на гнев библиотекара и где никако није пожељно доћи у последњи час, док се, са друге стране, библиотека појављује као место које је даноноћно отворено, где можемо у потпуности на најбољи и најсвеобухватнији начин сагледати и упознати себе, као и однос нас самих и околног света. Слика библиотеке као свезнајућег и свевидећег организма, може се рећи, овде се налази на клацкалици између рајског и пакленог места.

\section{Закључак}

Анализирање и разоткривање представа библиотеке и библиотекара у уметничкој књижевности и популарној литератури испоставља се као надасве занимљив, али и захтеван подухват. Отежавајући моменат је што се у делима савремених домаћих писаца библиотеке и библиотекари појављују ретко, а као главни ликови још ређе. Заговарање и лобирање код писаца са којима су библиотекари често у свом раду веома блиско повезани, овде се намеће, рекли бисмо, као потребна и посве легитимна појава, јер улога књижевног стваралаштва на креирање слике о библиотекама и библиотекарима у јавности није занемарљива. На основу дела наведених у овом раду, кроз која смо сагледавали слику о библиотекама и библиотекарима, тешко је одредити тачан степен преовладавања позитивних, односно негативних стереотипа. Сумирања ради, могло би се рећи, да је у књижевности за децу тренутно приметна тенденција јачања позитивних стереотипа. Тако слика младих, лепих и образованих и услужних библиотекара преузима престо строгим, суздржаним и намрштеним припадницима ове професије. У књижевности за одрасле срећу се озбиљне, круте, строге, повучене, недруштвене, слабо плаћене особе смештене у „библиотечкој тишини”. Но, са јачањем делатности односа са јавношћу у библиотекама постепено ти традиционално негативни стереотипи ишчезавају, а појављује се слика библиотекара који се залажу за своју професију, стоје чврсто иза свог система вредности и умеју да га одбране са осмехом.

\footnotetext{
22 Драгомир Ћулафић био је дугогодишњи управник у библиотеци „Лаза Костић” на Бановом брду. Оливера Недељковић ради у библиотеци „Владислав Петковић Дис" у Чачку. Љиљана Ђурђић, приређивач антологије Песме о библиоиеии, била је запослена у Народној библиотеци Србије.

${ }^{23}$ Zoran Živković, Biblioteka (Beograd: Everest media, 2008).

${ }^{24}$ Autostoperski vodič kroz fantastiku, https://fantasticnivodic.com/2017/06/05/naucna-fantastika/biblioteka-zoran-zivkovic/ (preuzeto 26. 8. 2017).
} 
Матијевић М. и др. „Библиотеке и библиотекари у уметничкој књижевности и популарној литератури”, 13-20

У домаћој литератури за децу и одрасле библиотекари и библиотеке јављају се као књижевни јунаци у делима писаца који су и сами били или су још увек библиотекари. Овај феномен би се могао протумачити настојањем библиотекара да и овим путем покушају да приближе јавности библиотекарство као професију. Користећи неформални разговор као методу анкетирања, у циљу проналажења што већег броја књижевних дела у којима се појављују библиотеке и библиотекари, изненађује и да се сами библиотекари нису лако могли сетити књига у којима је у фокусу професија којом се баве. Један од закључака који произилази иза ове анализе је да библиотекари имају моћ да руше стереотипе и обликују представе о себи, али да је морају јачати и освешћивати. Књижевни свет функционише по сопственим правилима, али преплитања библиотечког и уметничког света су неминовна. Која ће опција да превагне на клацкалици између библиотеке као рајског или пакленог места зависи у највећој мери од оних који су се, намерно или случајно, нашли у професији библиотекара.

\section{Литература и извори:}

1. Atterbury, Ilene Ramirose. "Perceptions of a profession: Librarians and stereotypes in online videos". Library Philosophy and Practice (e-journal) (2010): 433. http://digitalcommons.unl.edu/libphilprac/433 (preuzeto 20. 6. 2017).

2. Autostoperski vodič kroz fantastiku. https://fantasticnivodic.com/2017/06/05/naucna-fantastika/ biblioteka-zoran-zivkovic/ (preuzeto 26. 8. 2017).

3. Banićević, Morea. Demon školske biblioteke. Beograd: Laguna, 2016.

4. Eko, Umberto. Ime ruže. Beograd: Novosti, 2004.

5. Đurđić, Ljiljana, prir. Pesme o biblioteci. Beograd: NBS, 2003.

6. Ćulafić, Dragomir. "Moj tata liči na biblioteku". U Da ti šapnem, 83. Zrenjanin: Gradska narodna biblioteka "Žarko Zrenjanin“, 2010.

7. Ivković, Violeta. Trpezarija. Pančevo: Mali Nemo, 2009.

8. Jaćimović, Jelena i Ružica Petrović. „Stereotipi bibliotekara u javnosti, popularnoj kulturi i stručnoj literaturi. Infoteka god 15, 1 (2014): 56-66.

9. Agata, Kristi. Leš u biblioteci. Beograd: BIGZ, 1991.

10. Majid, Shaheen and Azim Haider. "Image problem even haunts hi-tech libraries: Stereotypes associated with library and information professional in Singapore". Aslib Proceedings 60, 3 (2008): 229-241.

11. Matijević, Vladan. „Šta li sada radi Olivera Jeremić”. U Pristaništa. Zrenjanin; Novi Sad: Agora, 2014.

12. Mazeti, Katarina. Frajer sa susednog groba. Beograd: Odiseja, 2012.

13. Nedeljković, Olivera. „Kad se tama spusti na glavni gradski trg”. Slova na struju 20 (2016): 238. http:// www.jabooka.org.rs/product/casopis-br-20/ (preuzeto 10. 7. 2017).

14. Safon, Karl Luis. Groblje zaboravljenih knjiga. Beograd: Čarobna knjiga, 2017.

15. Stevanović, Branko. „Dečaci iz biblioteke”, 7-8. U Ovako je to bilo. Novi Sad: Dnevnik, 2010.

16. King, Stephen. Knjižnički policajac. Virovitica: TWIN PRES, 2012.

17. Zan, Keti. Nikad ne reci nikad. Beograd: Vulkan, 2015.

18. Živković, Zoran. Biblioteka. Beograd: Everest media, 2008. 


\title{
Libraries and Librarians in Artistic and Popular Literature
}

\begin{abstract}
Summary
This paper analyses the depiction of libraries and librarians in contemporary Serbian literature. Although rarely used as a motif in works of Serbian authors, they are still present, in both children's literature and different literary genres for adults. The paper examines the typical stereotypes upon which the image of libraries and librarians is generated. Furthermore, it reveals some new, contemporary ones, which have been gradually replacing those from previous times. By presenting some works of literature, we are investigating the role of literature in creating a public image of libraries and librarians, as well as the extent to which contemporary Serbian literature contributes to the existing stereotypes or opposes them. Based on the works listed in this paper, through which we observe the image of libraries and librarians, it is difficult to determine the exact prevalence of either positive or negative stereotypes. However, it could be said that in children's literature there is a visible tendency of strengthening the positive stereotypes, while in literature for adults, the negative stereotypes are still widely used. The paper reviews the extent to which librarians are aware of prevailing image of themselves and their profession in contemporary Serbian artistic and popular literature. In it, librarians and libraries are presented as literary heroes mostly in the works by authors who were, or still are, librarians. This phenomenon could be explained as their attempt to shed light upon librarianship as a profession. Librarians-writers are those who most often bring the profession of a librarian into literary works. They make librarians literary characters and influence the creation and breaking down of both positive and negative stereotypes.
\end{abstract}

Keywords: libraries, librarians, stereotypes, literature, heroes, books

Примљено: 2. септембра 2017. Исправке рукописа: 23. септембра 2017. Прихваћено за објављивање: 29. септембра 2017. 